\title{
Leadership Styles of Principals and Teachers of Nigerian Unity Schools: Using School Environment as a Tool for School Achievement
}

\author{
Khalil Yusuf Uthman (Corresponding Author) \\ Federal College of Education Zaria, Nigeria \\ Tel \# +60143461839Ｅ-mail: yusufkhalil63@ gmail.com
}

Associate Professor Dr. Yahya Bn Don

School of Education and Modern Languages

Awang Had Saleh College of Arts and Sciences, Universiti Utara Malaysia

E-mail: d.yahya@uum.edu.my

\author{
Associate Professor Dr Abd Latif Kasim \\ School of Education and Modern Languages \\ Awang Had Saleh College of Arts and Sciences Universiti Utara Malaysia \\ E-mail: 1.kasim@uum.edu.my
}

Doi:10.5296/ jpag.v5i4.8865 URL: http://dx.doi.org/10.5296/ jpag.v5i4. 8865

\begin{abstract}
Collaborative, non-traditional leadership practices have attracted little attention in research about sustainable school achievement in Nigerian unity schools. The involvement of teachers in the administration of schools is well justified and arise from the need to boost school environment for the sake of attaining school achievement. The absence of teachers in the administration of unity schools impedes the proper attainment of school achievement. The purpose of this research is to reports on the outcomes of transformational leadership efforts in Nigerian unity schools aimed at enhancing the use of teachers in the administrative set-up. This study was carried out in seven selected unity schools all located in the north-eastern part of Nigeria. The study used Multifactor questionnaire 5x, School level environment questionnaire (SLEQ) and School Improvement questionnaire (SIQ) with 5 Likert-scale that involved the use of 800 questionnaires which were sent in which 790 were returned and 760 found valid for data analysis. Participants were drawn from a wide range of disciplines across
\end{abstract}


the sampled schools. The establishment and operation of these school relied on a transformational leadership methodology by principals that facilitates acts of initiative, innovation, vision and courage through group interaction rather than through designated hierarchical roles. This research used the quantitative approach. The study found out that transformational leadership approach is effective in overcoming problems associated with lack of involvement of teachers in the building of a fruitful environment capable of bringing a good school achievement through cultivating the habit of a transformational leader, the principals of unity schools enabled teachers and other stake holders to engage in peer-led professional learning, collaborative curriculum and pedagogical development, and to facilitate wider institutional change (school achievement). This paper demonstrates that the transformational leadership model for a high school achievement reported here is effective in building capacity for both teachers and students via involvement of teachers in building the environment. The model is flexible enough for a variety of institutional settings, and hence, recommends the use of teachers in secondary school's administration.

Keywords: Principal leadership, unity schools, school achievement, transformational leadership, school environment

\section{Introduction}

This research was carried out in the 101 existing unity schools in Nigeria with special focus on the 14 that are situated in the north -western Nigeria, The researcher further sampled only seven schools as follows: (Federal Government Girls College Tambuwal, Federal Government College Sokoto, Federal Government Girls College Bakori, Federal Government College Kano Federal Government College Gusau, Federal Government Girls College Zaria and Federal Government College Anka).) There is great interest in educational leadership in the early part of the $21^{\text {st }}$ Century because of the widespread belief that the quality of leadership makes a significant difference to school and student outcomes. There is also increasing recognition that schools require effective leaders and managers if they are to provide the best possible education for their learners (Bush, 2007). There is obviously the need for an experienced leadership in every secondary school that can provide a needed school environment for a functional school achievement, it was reported that a useful school climate and culture encourages a useful school achievement, more specifically, effective schools are characterized by an orderly environment. Levine and Lezotte, 1990 are of the view that an orderly environment is rather associated with interpersonal relationships, than with regulations. Hence, Bush, (2007) stressed that Schools need trained and committed teachers but they, in turn, need the leadership of highly effective principals and support from other senior and middle managers who have the charisma to coordinate the school environment to produce a better school achievement.

Consequently, this study has no doubt in using the transformational leadership theory to achieve its set objectives in order to seek for remedy for teachers who were neglected in matters of school leadership and administration; hence, there is little or no proper attainment of schools goals and objectives, that is why (Dobson and Tomkinson, 2012) stated that 
teaching is an element that boost innovation and leadership qualities in teachers. This failure in addressing interdisciplinary environmental problems is a contributing factor in the struggle to attain school achievement, including failure to use teachers in the administrative or leadership process of unity schools.

The investigation intends to answer a research question whether there is any positive relationship between Leadership style, school environment and outcome variables of school achievement?

\section{Literature}

Transformational leadership is a leadership style that inspires and motivates followers to demonstrate commitment to a shared vision. Leaders engage in behaviors that clearly communicate high expectations to followers and encourage collegiality and cohesiveness. Transformational leadership was first defined in James Burns' (1978) work researching political leaders. He described the transformational leadership style as enacting change within an organization through changes in the perception of organizational values and achievement. The literature review went through some analysis of leadership styles as it affects school environment, after the consideration of numerous leadership styles, transformational leadership style was made the official style that can make a school leader (principal) achieve the goal of transforming the school he is charged to lead. A lot of efforts were exacted on trying to establish a clear definition of leadership by scholars and theorists around the world. All the efforts ended-up in trying to give a solution to the bottle-necks like;

1) What are the personal traits or features of a good leader?

2) What are the patterns of a good leadership behavior?

3) What are leader's approaches to decision making?

4) How do leaders respond to acquire the support of their followers?

The review of some literature in this research provides an opening to the study by way of bringing in some discourse on leadership styles that is the influence of leadership styles and school environment towards school achievement in Nigerian unity schools. The research ended-up with discussions in line with using the style to create a conducive school environment for a successful school achievement.

There are various definitions of leadership as ascribed by many schools of thought example; leadership style is seen by many scholars as a network pattern of control emanating from hierarchy of bureaucratic control which employs the use of workers in making organizational decisions to resolve technical difficulties (Miller \& Rowan, 2006). Bass (1990) suggested that, leadership is that effort exacted by a leader to be able to control followers without much problem in the achievements of goals and objectives. But a leader according to Pierce \& Newstrom (2006) is the act of exacting intentional authority on one or group of people, with the intention of pin-pointing action towards the accomplishment of some mutual goals that has instant effect on members of a group. On daily basis, leaders are charged with the responsibility of interacting with their followers by listening to their problems and directing 
them towards an intended success. Transformational leadership as the official theory employed in this research "is measured based on the explicit focus on position of the leaders in the development of followers" (Dansereau, Yammarino, \& Markham, 1995). Unity schools were controlled based on transactional leadership theory as investigation pin-pointed, where the leader is seen exchanging his power with the obedience of the followers. But today the leader mingles with the follower in other to achieve his set objectives. The major difference between transactional and transformational leadership is known to have originated with Downton (1973) even though it became apparently known through Burns' (1978) work on political leaders.

According to Burns (1978), a difference can be pointed between two forms of leadership:

(1) Transactional leadership is aligned to an exchange relationship between leader and follower. The follower offers obedience to the leader (e.g. productivity, and commitment to the organisation) and receives in return important and useful rewards (e.g. financial benefits). Therefore, transactional leaders work in exchanges with followers without any consideration for personal and/or joint change and development.

(2) Transformational leadership is observed when leaders mingled with followers in ways that enhance their creativity and motivation in the schools (Burns, 1978).

Transformational leaders associate with followers, considering their intrinsic motivation and confidence. Unlike transactional leadership, transformational leadership does not seek to maintain the status quo but provides a stimulus for change and innovation instead (Bass \& Avolio, 1994). Transformational leaders try to motivate others to achieve more than what is originally expected of them; they create a supportive organisational climate where individual needs and differences are acknowledged and respected (Bass, 1998). The building of trust and respect motivates followers to work for the accomplishment of shared goals. Thus, (Adeyemo, 2010) reported that transformational leaders as noticed in the unity schools, motivate followers to focus on the common good, through commitment to the mission and vision of the organisation.

School environment is serving as an instrument of change to most transformational leaders, it is serving as a tool for transforming the school. Perkins (2006), stated that, school environment is the learning environment created through the interaction of human beings relating with each other, with physical setting, and psychological atmosphere. The construct of school environment is generally seen as multidimensional and representative of shared perceptions of behavior (Van Houtte, 2005). A favorable school environment provides the structure within which students, teachers and other stake holders function cooperatively and constructively. Edmunds (1982) and Lezotte (1990) were well known in linking environment directly to school effectiveness. School environment has been found to positively affect school achievement (Coleman, \& Schlictin, 2007; Stewart, 2007), to positively influence a student's behavior (e.g., conduct problems, depression), and to impact the decision to remain in school (Loukas \& Murphy, 2007). 
Environment in simplest terms is described as the people's beliefs and perceptions of their workplace (Sackney, 1998). School environment basically comprises of a standard and acceptable amalgamation of three factors; the learner, the teacher and the learning content. Considering the classroom environment on the side of environment, we will understand that people at different level of socialization are associating and dependent on each other (Donald, Lazarus \& Lolwana 1997). When we observe the behavior of people, we notice that what they do is remarkably influenced by where they are. They sit and listen in symphony concerts; browse and read in libraries; run and throw balls in ballgames. These behaviors occur in behavior settings and the behaviors elicited and supported by these behavior settings are pretty much the same regardless of who the occupants are. A school may be regarded as an environment consisting of various behavior settings: reading circles, arithmetic lessons, gymnasiums, instrumental music and classes. The behaviors of both pupils and teachers are influenced by the behavior backgrounds they occupy. We might further propose that how a teacher manages a group of pupils is dependent upon the behavior setting.

The cognitivist school of thought is chosen to explain the theory of school environment, cognivism came to the forefront in the second half of the twentieth century when researchers found that behaviorism did not account for all types of learning (Gagnes, 1984). Cognitivist rejects the behaviorist approach which excludes mental processes (e.g. thinking, memory, knowing and problem solving) in its explanation of how people learn, limiting learning to observable changes in behavior alone. Cognitivist focuses on the study of mental processes and uses it to explain learning. This view compares the mind to a 'black box'-one that needs to be opened and explored. The black box like a computer, receives information, processes it and then produces an output that may be stored in the mind or exhibited in behavior (Semple, 2000).

Knowledge can be viewed as schema, that is, symbolic mental constructions that are organized or processed in the mind, learning occurs when there is a change in the learner's schemata. As such, the learner is an active participant in the learning process, and his/her actions are a result of thought.

The environmental connection of this theory is that, learning environments created around this paradigm encourages curiosity; provide inquiry-oriented projects and present knowledge in staged scaffolding. Similar to behaviorism, cognitivist were typically laid out like campuses and were not often fenced in. They were usually single or two-story buildings connected by various walkways, which provided opportunities for the students to interact with the outdoors periodically, supporting the explorative approach of the learning theory. The classroom buildings housed students according to their grades, usually with several classes of one grade occupying a floor or a building-a response to the enrollment explosion brought on by the baby boomers. The classroom buildings were sequentially arranged and consisted of long corridors, flanked on both sides by classrooms. The internal layout of the classroom did not change much, however, the teacher's desk was still located at the head of the class and the students still sat in rows and faced the teaching wall. The Matawan Regional High School of Matawan, New Jersey was built in 1960 and is an example of a physical learning environment that responds to the cognitive learning theory. 


\section{$\triangle$ Macrothink}

The work of Freud shows how the truth or guilt resides in the intention, in unconscious intention. Actual crime is not the cause of guilt-feeling; rather is it the result of guilt-guilt that belongs to criminal intention. Only legal guilt refers to a crime; moral guilt refers to inner reality. Freud was able to make sense of this paradox. In his early theoretical formulations he was concerned with the id, by which he referred to the instinctual drives, and the ego, by which he referred to that part of the whole self that is related to the environment. The ego modifies the environment in order to bring about id-satisfactions, and it curbs id-impulses in order that what the environment can offer can be used to best advantage, again for id-satisfaction. Later (1923) Freud used the term superego to name that which is accepted by the ego for use in id-control. By my way of looking at things at the beginning we see a concentration of environmental phenomena in which there crystallizes out a person, a mother, and it is in the mother that the infant begins to appear first as an anatomical and a physiological unit, and then gradually, at about the birth date, becomes a male or a female person. This infant member of 'the nursing couple' develops in his or her own right in so far as the environment does not fail in its various essential functions, functions which change in their emphasis and develop in their quality as the growth of the individual proceeds. Under the most favorable conditions, where continuity is preserved externally and the facilitating environment allows the maturational process to act, the new individual really starts and eventually comes to feel real, and to experience life appropriate to his or her emotional age.

School achievement is the desire of every well-meaning school administrator and it is defined as all the improvement found in schools in welfare of staff and student and academic performance across the schools Hallinger, (2014). The relationships between theory and practice in the field of education is one of long standing, as the title of this thesis. Generations of critics and theorists have lamented the minimal impact exerted by the various theories of education on the practices of schooling. This level of impact has hardly resulted from lack of effort. Indeed, the theory base of education is both large and varied, with recommendations ranging from the use of computers for drill and practice to mapping students' preferred modes of learning, all offered to increase the academic achievement levels of students. Most theories directed toward teaching and learning share two primary characteristics:

- First, they are based on generalized notions of how people learn, notions drawn largely from the field of educational psychology and developed frequently in controlled laboratory settings Hinely, R, (1979).

-Second, the majority of theories concerning teaching and learning are intended, if only implicitly, to increase student achievement, to enhance student self-concept, or to correct some of the supposed ills of the enterprise of schooling. They are intended, in other words, to improve knowledge Kounin, (1979).

Several key elements separate improvers and describers in their approaches to the development and utilization of theory. One of the foremost differences between these groups lies in the questions they ask. The primary question for researchers interested in improvement is: How can things be changed? For describers, at least three questions are of key importance: 
1) A descriptive question-What seems to be happening here?

2) An analytical question-Why are these events occurring?

3) And a question of understanding-What do these events mean in the context of the school?

Perhaps an illustration will serve to better elucidate these differences. The ascendance of research oriented toward describing and understanding school phenomena and their effects has also led to increased activity in related areas of study such as the occupation of teaching and the school lives of students. The growing body of research intended toward school achievement describes an increasingly difficult portrait of the academic and behavioural systems existing there.

The theory supporting this concept of school achievement is the achievement goal theory. The most recent embodiment of the motives-as-goals tradition is achievement goal theory (e.g. Ames 1992, Dweck 1986, Urdan 1997, and Urdan \& Maehr 1995). The basic contention of achievement goal theory is that depending on their subjective purposes, achievement goals differentially influence school achievement via variations in the quality of cognitive self-regulation processes. Cognitive self-regulation refers to students being actively engaged in their own learning, including analyzing the demands of school assignments, planning for and mobilizing their resources to meet these demands, and monitoring their progress toward completion of assignments (Pintrich 1999, Zimmerman et al 1994). Therefore one's achievement goals are thought to influence the quality, timing, and appropriateness of cognitive strategies that, in turn, control the quality of one's accomplishments.

There are basically two general kinds of goals that are closely followed by the original approach and or avoidance position of need theory that have made a particular focus of study:

a) learning goals and

b) performance goals,

Although researchers have given preference to different designations for learning goals, such as task-goals (Anderman \& Midgley 1997, Midgley et al 1998, Nicholls 1984) or mastery goals (Ames 1992, Roberts 1992), there is general belief that irrespective of these differences, learning goals refer to increasing one's competency, understanding, and appreciation for what is being learned. Likewise, there is general agreement that performance goals, whether referred to as ego-goals (Nicholls 1989, Thorkildsen \& Nicholls 1998) or self-enhancing goals

(Skaalvik 1997), involve outperforming others as a means to upgrade one's ability status at the expense of peers.

\section{Findings}

\section{Descriptive statistics of variables investigated}

The personal data selected along the opinion on influence of leadership style and school 
environment towards students' academic achievement in the selected Unity Schools were sex, age, educational level and the condition of employment in the unity schools along with duration in the school and department. Each of the variables is classified in frequencies and percentages in this section. The study used Multifactor questionnaire 5x, School level environment questionnaire (SLEQ) and School Improvement questionnaire (SIQ) with 5 Likert-scale that involved the use of 800 questionnaires which were sent in which 790 were returned and 760 found valid for data analysis. The performances of the final year candidates in their terminal examinations were used for the dependent variable in the determinant of the influence of the leadership styles. Of the total respondents 431 or $59.5 \%$ were male while the female were 329 or $40.5 \%$. This classification though not equitably distributed, revealed that the opinions of male and female respondents were solicited. This helps to take off the gender bias aspect of the study and is more so since the influence of leadership style on the school environment and students' academic achievement in the selected Unity Schools would not be assessed on the bases of gender.

For the ages of the respondents, only 92 or $8.2 \%$ were below 30years. Those who were between 30 and 40years were 240 or $36.1 \%$ while 362 or $53.8 \%$ were between the range of 41 and 50years with 66 or $1.9 \%$ above 50years. This distribution is attributable to the fact that all the respondents were of adult working age. Their opinion on the influence of leadership style on the school environment and students' academic achievement in the selected Unity Schools would therefore be expected to reflect this maturity.

By educational qualification, 425 or $65.2 \%$ were first degree holders and 335 or $34.8 \%$ have second degree or masters. The predominant of first degree is more associated with the requirement for teaching qualification in the selected schools. Only 124 or $13.4 \%$ of the respondents were on part time tenure of appointment in the schools. Mots (636 or 86.6\%) were on full time tenure. The respondents cut across all disciplines in the selected unity schools.

The descriptive statistics (mean standard deviation and standard errors) of the item cum variables investigated are presented in Table 4.1. The aggregate mean scores of the total items for school environment, school achievement and the students' terminal examination performances were used as dependent variables on which the influence of the leadership styles was determined. The items used for assessing the leadership styles were not summed up for aggregate mean score because of the need to determine the uniqueness of leadership styles or traits and their possible influences on the selected dependent variables (school environment, school achievement and students' academic performances). For items cum variables measured on the five point scale decision is based on 3.5 for agreement while 3.4 and below are for disagreement. 
Table 1: Descriptive Statistics of items and variables investigated

\begin{tabular}{|c|c|c|c|}
\hline Variables & Mean & Std. Dev. & Std. Error \\
\hline $\begin{array}{l}\text { My principal provide other with assistance in exchange for } \\
\text { their effort }\end{array}$ & 4.04 & 0.968 & 0.049 \\
\hline $\begin{array}{l}\text { My principal re-examines critical assumption to questions } \\
\text { whether they are appropriate }\end{array}$ & 3.78 & 0.903 & 0.046 \\
\hline My principal fail to interfere until problems become serious & 3.16 & 1.344 & 0.068 \\
\hline $\begin{array}{l}\text { My principal focus attention on irregularities, mistakes, } \\
\text { exceptions and deviations from standards }\end{array}$ & 3.83 & 1.122 & 0.057 \\
\hline $\begin{array}{l}\text { My principal avoid getting involved when important issues } \\
\text { arise }\end{array}$ & 3.05 & 1.386 & 0.070 \\
\hline $\begin{array}{l}\text { My principal talk about my most important values and } \\
\text { benefits }\end{array}$ & 3.76 & 0.967 & 0.049 \\
\hline My principal is absent when needed & 3.07 & 1.402 & 0.071 \\
\hline $\begin{array}{l}\text { My principal seek differing perspectives when solving } \\
\text { problems }\end{array}$ & 3.94 & 0.965 & 0.049 \\
\hline My principal talk optimistically about the future & 3.90 & 0.926 & 0.047 \\
\hline $\begin{array}{l}\text { My principal instill pride in others for being associated with } \\
\text { me }\end{array}$ & 3.68 & 1.035 & 0.053 \\
\hline $\begin{array}{l}\text { My principal discuss in specific terms who is responsible for } \\
\text { achieving performance targets }\end{array}$ & 3.86 & 0.939 & 0.048 \\
\hline $\begin{array}{l}\text { My principal wait for things to go wrong before taking } \\
\text { action }\end{array}$ & 3.23 & 1.453 & 0.074 \\
\hline School environment & 3.80 & 0.525 & 0.027 \\
\hline School achievement & 2.14 & 0.270 & 0.014 \\
\hline Students' academic Performance & 68.30 & 26.525 & 1.347 \\
\hline Aggregate leadership mean score & 3.6091 & .03108 & .61215 \\
\hline
\end{tabular}

The mean sores in the table revealed that most of the principals have the traits of providing 
staff with assistance in exchange for their effort and examines critical assumptions to questions in terms of their appropriateness. These are clearly indicated with high mean scores of 4.04 and 3.78 for the first two leadership styles in the table. This could explain the respondents score of item 4 where they agreed that the leadership style of their principals was such that they focus attention on irregularities, mistakes, exceptions and deviations from standards. This tally with styles of talking about staff most important values and benefits, seeking differing perspectives when solving problems and talking optimistically about the future which were associated with the leadership styles of the principals in the table. The positive traits included instilling pride in others for being associated with them and discussion of specific terms on who is responsible for achieving performance targets.

But most respondents did not agree that that their principals usually fail to interfere until problems become serious in the schools or that their principals usually try to avoid getting involved when important issues arise and that the leader (principal) is always is absent when needed. The respondents did not agree that the principals wait for things to go wrong before taking action. The aggregate leadership styles score of 3.61 in the table clearly shows that the respondents actually found the leadership adequate. These observations clearly portray a positive leadership styles which the respondents tended to associate with the leadership of the selected Unity schools involved in the study.

For the school environment, the score of 3.80 clearly imply that the respondents were of the view that it was satisfactory and adequate. But this was not the same with school achievement with a mean score of 2.14 which imply that the respondents did not agree that it could be considered adequate. Students' academic performance was not generally bad with an average performance of $68.3 \%$ in the terminal examinations. The influence of the principals' leadership styles on these variables are investigated below. Research question: Is there any positive relationship between leadership styles, school environment and school achievement in Nigerian unity schools? The aim here is to determine the relationship of leadership style towards school environment and outcome variables of school achievements in Nigerian unity schools. The related hypothesis used for the investigation is Hypothesis: There is significant positive relationship between leadership styles, school environment and school achievement in Nigerian unity schools. The aggregate mean scores of all the leadership traits was computed here and used as a single variable to correlate the school environment and the outcome variables of school achievement and students' academic performance in the terminal examinations. The four variables were correlated using the Pearson Product Moment correlation procedure and the result is summarized in a matrix in Table 4.3.9. 
Table 2: Relationship between leadership style, school environment and output variables of school achievement and students' academic performance

\begin{tabular}{|l|l|l|l|l|}
\hline Variables & $\begin{array}{l}\text { School } \\
\text { environment }\end{array}$ & $\begin{array}{l}\text { School } \\
\text { achievement }\end{array}$ & $\begin{array}{l}\text { Students } \\
\text { academic } \\
\text { performance }\end{array}$ & $\begin{array}{l}\text { Leadership } \\
\text { style }\end{array}$ \\
\hline School environment & 1 & $.355(* *)$ & $-.171(* *)$ & $.810(* *)$ \\
\hline School achievement & $.355(* *)$ & 1 & .015 & $.253(* *)$ \\
\hline $\begin{array}{l}\text { Students' academic } \\
\text { performance }\end{array}$ & $-.171(* *)$ & .015 & 1 & $-.109(*)$ \\
\hline Leadership style & $.810(* *)$ & $.253(* *)$ & $-.109(*)$ & 1 \\
\hline & 388 & 388 & 388 & 388 \\
\hline
\end{tabular}

** Correlation is significant at the 0.01 level (2-tailed).

* Correlation is significant at the 0.05 level (2-tailed).

The result indicates that aggregate leadership style is positively and significantly correlated with the school environment, and school achievement. But it was negatively and significantly correlated with students' academic performance. The school environment was significantly and positively correlated with school achievement and negatively but significantly correlated with students' academic performance.

\section{Summary of findings and Discussion}

The major observations of this study are that positive and significant relationship was obtained between leadership styles, school environment and school achievement, and, hence, the alternative hypothesis is retained. This is evident in the saying of most scholars such as pekins, (2006) stressed that school environment is the learning environment created through the interaction of human beings relating with each other, with physical setting, and psychological atmosphere. It was equally observed by other scholars that the construct of school environment is generally seen as multidimensional and representative of shared perceptions of behavior (Van Houtte, 2005). A favorable school environment provides the structure within which students, teachers and other stake holders function cooperatively and constructively. Edmunds (1982) and Lezotte (1990) were well known in linking environment directly to school effectiveness. School environment has been found to positively affect school achievement (Coleman, \& Schlictin, 2007; Stewart, 2007), to positively influence a 
student's behavior (e.g., conduct problems, depression), and to impact the decision to remain in school (Loukas \& Murphy, 2007).

But the relationship between Leadership styles and students' academic achievement was statistically significant but not positive. This findings contradicts the report of Lambert, (2003) were he stated that most researchers are of the opinion that if school leadership is improved, there are bound to be improved academic performance in schools. And the negative relationship obtained here also reflected on the report of Leithwood,(2004) in which he said that certain styles of leadership pays attention to a more complex but clear classroom condition that needs to be changed if learning actually needs to be improved.

\section{Recommendations}

Based on the findings in this study, the researcher would want to recommend as follows:

1. There is a need for a continuous evaluation of the leadership styles of principals in the Unity schools towards the inclusion of teachers in school's leadership for effective and positive school achievement outcome.

2. Principals should examine the performances of their students and the school achievement measured by teachers' performances from time to time Vis a Vis their leadership styles towards adjustment for positive outcome.

3. There is a need for principals to harmonize their leadership styles with teachers and students' needs such that the central goals of the school including academic performance could be achieve.

4. Style of leadership should be a determining factor in the selection of principals especially where such personnel have been staff of the school for some time.

5. Stakeholders of secondary schools should be involved in periodical evaluation of principals' leadership styles as measured from students' academic performances on a periodical basis.

\section{References}

Austin, G, \& Reynolds, D. (1990). Managing for improved school effectiveness; An International survey. School Organization, 10(2/3), 167-178.Retrieved September 23, 2013, from psyc ARTICLES database.

A'Campo, C. (1993). Collaborative school environments: How principals make a difference. School Organization, 13, 119-127. 


\section{Macrothink}

Journal of Public Administration and Governance ISSN 2161-7104 2015, Vol. 5, No. 4

Andrews, R. L., \& Soder, R. (1987). Student achievement and principal leadership. Educational Leadership, 44(6), 9-11.

Ash, R., \& Persall, M. (1999). The principal as chief learning officer. National Association of Secondary School Principals, 84(616), 15-22.

Akinwumiju, J. A, Olaniyan DA (1996). Supervision, Leadership and administration; the evasive concepts in school Management" Ibadan; Education study and Research Group.Pp.21-45.

Akinyemi A (1993). Job satisfaction among teachers in Ondo state secondary schools'. J. Educ. Leadership, 29; 10-22.

Ball, S. J. (1987), the micro-Politics of the School; towards a theory of school organization. Cambridge, Cambridge University Press.

Barber, B. (1992). An aristocracy of everyone; the politics of education and the future of America. New York; Ballantine Books.

Bandura, A. (1977). Self-efficacy: Toward a unifying theory of behavioral change. Psychological Review, 84, 191-215.

Bandura, A. (1993). Perceived self-efficacy in cognitive development and functioning .Educational Psychologist, 28, 117-148.

Barth, R. S. (1980). Run school run. Cambridge: Harvard University Press.

Bass, B. M. (1985). Leadership and performance beyond expectations. New York: Free Press.

Bass, B. M., \& Avolio, B. J. (1990) Transformational leadership development: Manual for the Multifactor Leadership Questionnaire. Palo Alto, Consulting Psychologists Press.

Bass, B. M., \& Avolio, B. J. (1993). Transformational leadership: A response to critiques. In M. M. Chemers \& R. Ayman (Eds.), Leadership theory and research: Perspectives and directions (pp. 49-88). San Diego, CA: Academic.

Bass B. M., Waldman, D. A., Avolio, B. J., \& Bebb, M. (1987). Transformational leadership and the falling dominos effect. Group and Organizational Studies, 12, 73-87.

Beare, H., Caldwell, B. J., \& Milliken, R. H. (1989). Creating an excellent school: Some new management techniques. New York: Routledge.

Bennis, W. (1989). On becoming a leader. Reading, PA: Addison-Wesley.

Blanchard, K., Carlos, J., \& Randolph, A. (1996). Empowerment takes more than aminute. San Francisco: Berrett-Koehler. 69

Blasé, J., \& Anderson, G. (1995). The micropolitics of educational leadership: From control to empowerment. New York: Cassell. 


\section{Macrothink}

Journal of Public Administration and Governance ISSN 2161-7104 2015, Vol. 5, No. 4

Blasé, J., \& Blasé, J. (1996). The fire is back: Principals sharing school governance. Thousand Oaks, CA: Corwin.

Bolman, L. G., \& Deal, T. (1984). Modern approaches to understanding and managing organizations. San Francisco: Jossey-Bass.

Bolman, L. G., \& Deal, T. (1991). Reframing in action. San Francisco: Jossey-Bass.

Bolman, L. G., \& Deal, T. (1995). Leading with soul: An uncommon journey of spirit. San Francisco: Jossey-Bass.

Brewer, D. (1993). Principals and student outcomes: Evidence from U.S. high schools. Economics of Education Review, 12, 281-292.

Brookover, W. B., Schweitzer, J. H., Schneider, J. M., Beady, C. H., Flood, F. K., \&Wisinbaker, J. M. (1978). Elementary school social climate and school achievement. American Educational Research Journal, 15, 301-318. 